\title{
Evaluation of the factors affecting silage intake of dairy cows: a revision of the relative silage dry-matter intake index
}

\author{
P. Huhtanen ${ }^{1 \dagger}$, M. Rinne ${ }^{1}$ and J. Nousiainen ${ }^{2}$ \\ ${ }^{1}$ MTT Agrifood Research Finland, Animal Production Research, FI-31600, Jokioinen, Finland; ${ }^{2}$ Valio Ltd, Farm Services, PO Box 10, FI-00039 Valio, Finland
}

(Received 10 October 2006; Accepted 23 February 2007)

An evaluation of the factors affecting silage dry-matter intake (SDMI) of dairy cows was conducted based on dietary treatment means. The data were divided into six subsets based on the silage treatments used in the experiments: concentration of digestible organic matter in dry matter ( $D$-value) influenced by the maturity of grass ensiled $(\mathrm{n}=81)$, fermentation quality influenced by silage additives $(n=240)$, dry matter $(D M)$ concentration influenced by wilting of grass prior to ensiling $(W ; n=85)$, comparison of silages made from primary growth or regrowth of grass $(n=46)$, and replacement of grass silage with legume $(L ; n=53)$ or fermented whole-crop cereal (WC; $\mathrm{n}=37$ ) silages. The data were subjected to the mixed model regression analysis. Both silage $D$-value and fermentation quality significantly affected SDMI. The average effects of D-value and total acid (TA) concentration were $17.0 \mathrm{~g}$ and -12.8 per $1 \mathrm{~g} / \mathrm{kg} D \mathrm{M}$, respectively. At a given D-value, silage neutral-detergent fibre (NDF) concentration tended to decrease SDMI. Silage TA concentration was the best fermentation parameter predicting SDMI. Adding other parameters into the multivariate models did not improve the fit and the slopes of the other parameters remained insignificant. Total NDF intake was curvilinearly related to silage $D$-value the maximum intake being reached at a D-value of $640 \mathrm{~g} / \mathrm{kg} \mathrm{DM}$. Results imply that physical fill is not limiting SDMI of highly digestible grass silages and that both physical and metabolic factors constrain total DM intake in an interactive manner. Silage DM concentration had an independent curvilinear effect on SDMI. Replacing primary growth silage with regrowth, L or WC silages affected SDMI significantly, the response to regrowth silage being linearly decreasing and to $L$ and WC quadratically increasing. The outcome of factors affecting SDMI was used to update the relative SDMI index as follows: SDMI index $=100+10 \times[(D$-value -680$) \times 0.0170-(T A-80) \times 0.0128+(0.0198 \times$ $\left.(D M-250)-0.00002364 \times\left(D M^{2}-250^{2}\right)\right)-0.44 \times a+4.13 \times b-2.58 \times b^{2}+5.90 \times c-6.14 \times c^{2}$ $-0.0023 \times(550-N D F)]$, where $a, b$ and $c$ represent the proportions $(0-1)$ of regrowth, $L$ or WC silages from total silage DM. For the whole data set, one index unit corresponded to the default value of $0.10 \mathrm{~kg}$ in SDMI. The SDMI index explained proportionally 0.852 of the variation in SDMI with $0.34 \mathrm{~kg}$ DM per day residual. The updated SDMI index provides improved basis for the practical dairy cow ration formulation and economic evaluation.

Keywords: digestibility, fermentation, fibre, food intake, forage

\section{Introduction}

Variation in the performance of ruminant animals is more closely related to feed intake than to diet digestibility or efficiency of converting digestible energy to metabolisable or net energy (Mertens, 1994). Consequently, accurate prediction of feed intake is a fundamental prerequisite for any effective ration formulation system for lactating dairy cows. Regulation of feed intake in ruminants involves multiple mechanisms that are poorly understood, and despite extensive research efforts over the past 30 to 40

\footnotetext{
${ }^{\dagger}$ Present address: Cornell University, Department of Animal Science, Morrison
} Hall, Ithaca, NY 14853-4801, USA. E-mail: Pekka.Huhtanen@mtt.fi years no generally accepted intake model has been developed. Limited success in developing the predictive models is at least partly due to complicated interactions between animal and feed characteristics. Many of the models use milk yield as an input variable (Vadiveloo and Holmes, 1979; Dulphy et al., 1989; National Research Council, 2001; Keady et al., 2004) but usefulness of such models in ration formulation may be questioned, since the final output (milk yield) is used to predict input (feed intake).

To overcome the problems resulting from variation in animal and environmental factors, we presented a relative silage dry-matter intake (SDMI) index using the data from milk production studies and mixed model regression 
analysis (Huhtanen et al., 2002). This approach allows estimating the effects of silage characteristics on drymatter (DM) intake when the animal and other dietary factors (e.g. concentrate supplementation and feeding management) are constant. Although based on data from different trials and a statistical method, our approach is similar to the attempts to adjust for differences between the animals by using a standard reference forage (Osbourn et al., 1974) or by estimating silage intake potential directly by near infra-red spectroscopy (NIRS; Agnew et al., 2001). The relative SDMI index (Huhtanen et al., 2002) was based on the concentration of digestible organic matter (OM) in silage DM (D-value) and some fermentation parameters, and it predicted differences in SDMI relatively accurately when D-value was affected by the stage of grass maturity at harvest and silage fermentation characteristics were modified by using different levels and types of silage additives.

However, in addition to D-value and fermentation characteristics, silage intake is influenced by silage DM concentration the SDMI responses often being greater for high DM silages than predicted from silage fermentation parameters (Gordon, 1981; Yan et al., 1996; Kokkonen et al., 2000). The intake of legume silages is often higher than that of grass silages (e.g. Heikkilä et al., 1992; Dewhurst et al., 2003) the effects being unpredictable from D-value and fermentation quality. Positive associative effects of feeding mixtures of whole-crop and grass silages have been reported although the D-value of whole-crop silages have been lower than that of grass silages (Hameleers, 1998; Jaakkola et al., 2001 and 2003; Patterson and Kilpatrick, 2005). There is also evidence that cows consume less regrowth silages compared with primary growth silages (Peoples and Gordon, 1989; Khalili et al., 2005; Kuoppala et al., 2005a) but the comparisons of silage harvest have in most cases been confounded by variations in D-value, DM concentration and fermentation characteristics.

The first objective of the present study was to update the relative SDMI index with new research data and extend it to include the effects resulting from variation in silage DM concentration, different harvests (primary growth $v$. regrowth) and forage types (inclusion of legume or wholecrop silages). The second objective was to estimate the effects of some animal and diet related factors on quantitative intake responses to one intake index unit. Further, the possible mechanisms influencing the intake responses to different forage factors are discussed.

\section{Material and methods}

Data acquisition

Mean treatment values were collected from dairy cow studies using ad libitum feeding of grass silage, or grass silage partly or completely replaced with legume or wholecrop silages. The list of references used to collect the database is provided in Appendix 1 available at: http:// www.animal-journal.eu/. The diets were supplemented with concentrate feeds differing both in amount and composition between but not within experiments. When several concentrate treatments were used within an experiment, they were considered as separate experiments in the statistical analysis. Approximately half of the experiments were conducted in UK, half in Finland and a few in Ireland and Sweden. For the Finnish experiments, also unpublished data was used. Variation in the design of experiments, milk yield, stage and number of lactation, feeding routines etc. between the experiments was substantial.

The data were divided into six subsets based on the silage treatments used in the experiment. The topics of the subsets were: digestibility influenced by the maturity of grass ensiled (D-value), silage fermentation quality influenced by silage additives (fermentation quality), silage DM concentration influenced by wilting of grass prior to ensiling (wilting), comparison of silages made from primary growth or regrowth of grass (harvest), and replacement of grass silage with legume (legume) or fermented wholecrop cereal (whole-crop) silages. Characterisation of the different subsets is presented in Table 1.

The minimum prerequisite for an experiment to be included in the data set was that silage and total DM intake, milk production and adequate silage characterisation (plant species, DM concentration, in vivo or in vitro digestibility, and fermentation quality) were reported. The concentration of total acids (TA) was calculated by summing the concentrations of lactic acid (LA) and volatile fatty acids (VFA). Energy-corrected milk (ECM) yield was calculated according to Sjaunja et al. (1991). For the Finnish data, silage D-values based on in vitro pepsincellulase method were corrected with forage-specific equations (primary growth and regrowth grass, legume and whole-crop silages; Huhtanen et al., 2006). When silage neutral-detergent fibre (NDF) and indigestible NDF (iNDF) concentrations were not reported, estimates derived from regression equations based on the Finnish data sets (Huhtanen et al., 2006) were used.

\section{Calculations and statistical analysis}

The data were analysed using the mixed model procedure of SAS (Littell et al., 1996). The model was:

$$
Y=B_{0}+B_{1} X_{i j}+b_{0}+b_{i} X_{i j}+B_{2} X_{i j}+B_{3} X_{i j}+e_{i j}
$$

where $B_{0}+B_{1} X_{i j} \ldots+B_{3} X_{i j}$ are the overall fixed effects, $b_{0}, b_{1}$ (intercept and slope) and $e_{i j}$ are the random part of the model, $i=1 \ldots n$ studies and $j=1 . . . k$ values within study. In multivariate models only the first independent variable was a random factor. Variation in experimental protocols, animal types and laboratory assays would contribute to study effects in these regressions. The best fit model was chosen based on the lowest residual mean square error (RMSE) and the lowest Akaike's corrected information criteria. In the tables RMSE and $R^{2}$ values 
Huhtanen, Rinne and Nousiainen

Table 1 Description of the sub-datasets derived from treatment means of previously conducted milk production experiments ${ }^{\dagger}$. The reference numbers refer to Appendix 1 available at: http://www.animal-journal.eu/

\begin{tabular}{|c|c|c|c|c|c|c|c|c|c|c|}
\hline & \multicolumn{2}{|c|}{$\begin{array}{c}\text { DM intake } \\
\text { (kg/day) }\end{array}$} & \multirow[b]{2}{*}{ Milk (kg/day) } & \multicolumn{2}{|c|}{ In milk $(\mathrm{g} / \mathrm{kg})$} & \multicolumn{5}{|c|}{ Silage characteristics (g/kg DM) } \\
\hline & Forage & Total & & Fat & Protein & $\mathrm{DM}(\mathrm{g} / \mathrm{kg})$ & D-value & NDF & Total acids & Ammonia- $\mathrm{N} \mathrm{g} / \mathrm{kg} \mathrm{N}$ \\
\hline \multicolumn{11}{|c|}{ Silage D-value (references $1,3,5,12,13,23,25,34,48,52,61,62$ ) } \\
\hline$n$ & 81 & 81 & 81 & 81 & 81 & 81 & 81 & 46 & 52 & 81 \\
\hline Mean & 10.5 & 17.6 & 24.5 & 43.0 & 32.4 & 250 & 670 & 551 & 86 & 71 \\
\hline s.d. & 2.13 & 2.89 & 4.21 & 4.45 & 1.41 & 37.2 & 46.9 & 62.3 & 30.4 & 30.3 \\
\hline Minimum & 5.4 & 10.5 & 13.4 & 35.1 & 29.1 & 163 & 551 & 479 & 18.5 & 31 \\
\hline Maximum & 17.4 & 25.2 & 33.8 & 54.1 & 35.7 & 393 & 756 & 647 & 146.1 & 154 \\
\hline \multicolumn{11}{|c|}{ Silage additive treatment (references $4,7,8,9,17-23,25,29-32,34,35,37,38,40,45-47,49,54-59,65-67,69,71$ ) } \\
\hline$n$ & 240 & 240 & 240 & 240 & 240 & 240 & 240 & 128 & 240 & 240 \\
\hline Mean & 10.7 & 17.3 & 23.9 & 43.6 & 31.9 & 253 & 671 & 528 & 96 & 67 \\
\hline s.d. & 1.76 & 2.71 & 4.68 & 3.39 & 1.81 & 57.5 & 35.8 & 39.7 & 39.5 & 30.4 \\
\hline Minimum & 5.3 & 10.9 & 13.3 & 34.3 & 25.9 & 163 & 588 & 458 & 8 & 12 \\
\hline Maximum & 15.9 & 23.6 & 34.3 & 51.6 & 35.9 & 474 & 751 & 634 & 218 & 179 \\
\hline \multicolumn{11}{|c|}{ Wilting (references $4,6,12,14,15,28,30,38,43,44,48,51,53,57,59,60,63,68$ ) } \\
\hline$n$ & 85 & 85 & 85 & 85 & 85 & 85 & 85 & 37 & 71 & 85 \\
\hline Mean & 10.4 & 17.8 & 24.4 & 43.3 & 32.9 & 299 & 674 & 531 & 80 & 65 \\
\hline s.d. & 1.88 & 3.05 & 5.86 & 3.68 & 1.55 & 99.5 & 51.6 & 42.6 & 50.0 & 28.9 \\
\hline Minimum & 6.2 & 12.1 & 13.3 & 35.8 & 29.4 & 176 & 495 & 441 & 7 & 13 \\
\hline Maximum & 15.7 & 24.9 & 38.2 & 50.0 & 35.9 & 695 & 756 & 596 & 188 & 158 \\
\hline \multicolumn{11}{|c|}{ Harvest (primary growth v. regrowth; references $24,36,43,44,50,52,60$ ) } \\
\hline$n$ & 46 & 46 & 46 & 46 & 46 & 46 & 46 & 36 & 46 & 46 \\
\hline Mean & 11.9 & 20.4 & 29.4 & 43.3 & 32.4 & 279 & 664 & 531 & 57 & 53 \\
\hline s.d. & 2.25 & 2.90 & 5.24 & 3.45 & 1.21 & 91.9 & 35.9 & 38.0 & 21.0 & 14.6 \\
\hline Minimum & 6.2 & 12.1 & 19.0 & 36.4 & 29.6 & 192 & 602 & 457 & 7 & 13 \\
\hline Maximum & 17.4 & 25.2 & 38.2 & 49.5 & 35.1 & 695 & 725 & 594 & 102 & 77 \\
\hline \multicolumn{11}{|c|}{ Inclusion of legume silages (references $2,10,26,27,32,33,39,64,70,72$ ) } \\
\hline$n$ & 53 & 53 & 53 & 53 & 53 & 53 & 53 & 53 & 48 & 53 \\
\hline Mean & 12.6 & 20.1 & 28.2 & 42.8 & 31.5 & 268 & 654 & 463 & 78 & 71 \\
\hline s.d. & 1.90 & 1.65 & 2.41 & 3.11 & 1.65 & 57.9 & 34.9 & 83.6 & 23.7 & 33.5 \\
\hline Minimum & 8.7 & 15.7 & 23.5 & 35.2 & 28.3 & 191 & 562 & 248 & 8 & 28 \\
\hline Maximum & 16.9 & 23.4 & 33.2 & 48.0 & 35.2 & 423 & 714 & 637 & 129 & 144 \\
\hline \multicolumn{11}{|c|}{ Inclusion of whole-crop silages (references $11,16,41,42$ ) } \\
\hline$n$ & 37 & 37 & 37 & 37 & 37 & 37 & 37 & 34 & 34 & 37 \\
\hline Mean & 11.9 & 20.1 & 28.0 & 44.2 & 32.8 & 268 & 646 & 512 & 68 & 43 \\
\hline s.d. & 1.26 & 2.42 & 3.54 & 3.30 & 0.91 & 41.7 & 43.0 & 41.7 & 12.3 & 13.3 \\
\hline Minimum & 9.0 & 13.7 & 19.8 & 39.9 & 31.1 & 192 & 548 & 394 & 49 & 19 \\
\hline Maximum & 14.2 & 23.1 & 33.5 & 50.0 & 34.3 & 378 & 705 & 562 & 93 & 69 \\
\hline
\end{tabular}

${ }^{\dagger} \mathrm{DM}=$ dry matter; NDF $=$ neutral detergent fibre.

after adjusting for the random effect of study are presented. Rationale and further details of using mixed model analysis to integrate quantitative findings from multiple studies are described by St-Pierre (2001).

The effects of a single silage characteristic influencing SDMI are often confounded by other factors (e.g. silages harvested at different stages of maturity may differ in the concentrations of DM and fermentation products) and therefore possible confounding factors were included in models to estimate e.g. the effects of D-value on intake at fixed concentrations of DM and fermentation products. Similarly, the silages were adjusted for the D-value and fermentation effects when the effects of silage DM concentration on SDMI were evaluated. When evaluating the effects of silage harvest (primary growth $v$. regrowth), the intakes were adjusted for differences in silage DM, D-value and fermentation characteristics.

The results from analysis of all six sub-datasets (D-value, fermentation quality, wilting, harvest, legume, and whole crop) were combined to create a relative SDMI index as described in our previous paper (Huhtanen et al., 2002). In the index, a difference of approximately $0.10 \mathrm{~kg}$ in SDMI is equal to one unit. The standard silage (100 units) was defined as follows: primary growth grass silage containing $250 \mathrm{~g}$ DM per $\mathrm{kg}, 680 \mathrm{~g} / \mathrm{kg}$ DM digestible organic matter and $80 \mathrm{~g} / \mathrm{kg}$ DM total acids. The lower limit for TA concentration for improving index scores was set to $50 \mathrm{~g} / \mathrm{kg}$ DM. 
Possible interactions between the index components were evaluated by bivariate regression models using all silage parameters as independent variables in addition to the estimated SDMI index. The residuals of the mixed model regression between SDMI and the index were plotted against all silage parameters using a simple regression of $Y$ on $X$.

To validate the robustness of the SDMI index model, the data were split experimental-wise into six subsets of 73 to 86 observations. Each subset was in turn left out and the SDMI index model was calculated with the remaining five sub-sets. The resultant model parameters were used to compute silage SDMI index for the observations in the excluded subset, and the procedure was repeated for all subsets (cross-validation). The cross-validation error $\left(\mathrm{RMSE}_{\mathrm{CV}}\right)$ was obtained by regressing observed SDMI against predicted SDMI for all cross-validation subsets using a mixed model regression analysis with random study effect as described above.

The effects of some animal and diet related parameters on the index responses to SDMI were estimated by simple regression on animal factors (e.g. milk yield, days in milk, total DM intake) on the slope of regression [ $Y$; fixed effect $\left(B_{1}\right)+$ random effect $\left.\left(b_{1}\right)\right]$.

\section{Results}

Silage digestibility as influenced by stage of maturity

Silage D-value was the best single predictor of SDMI when silages were harvested at varying stages of grass maturity (Table 2). The mean response in SDMI to improved D-value was $0.0175 \mathrm{~kg}$ per $1 \mathrm{~g} / \mathrm{kg}$ in $D$-value. When primary growth $(n=55)$ and regrowth $(n=26)$ silages were analysed separately, the regression coefficients of $D$-value were similar (0.0168 v. 0.0164). Including silage DM or ammonia $\mathrm{N}$ concentration in the model slightly reduced the prediction error compared with D-value alone, but the coefficient of D-value did not markedly change.

The effect of silage crude protein (CP) concentration on SDMI was not significant when used in a bivariate model with D-value. Including silage NDF concentration in the model with D-value decreased the regression coefficient of D-value and NDF had a significantly negative coefficient. Silage DM intake was much more closely associated to D-value than NDF concentration. However, when NDF was divided into iNDF and potentially digestible NDF (NDF iNDF; pdNDF), the precision of SDMI prediction improved markedly compared with NDF alone. Using OMD instead of $D$-value increased the prediction error, but when ash concentration was included in the model, the prediction error was similar to $\mathrm{D}$-value.

When the data were classified according to the mean milk yield within the study (below or above $25 \mathrm{~kg} /$ day), the response to increased $D$-value tended to be higher $(0.0210$ v. $0.0142 ; P=0.11)$ for the high yielding cows compared with the low yielding cows. The average energy-corrected milk (ECM) yields were 21.8 and $29.2 \mathrm{~kg} /$ day for the low and high yielding experiments, respectively.

Intake of NDF decreased $(P<0.05)$ with improved silage D-value (Table 3 ). The effect was curvilinear with the maximum NDF intake being observed at a D-value of $640 \mathrm{~g} / \mathrm{kg}$ DM. Silage NDF intake was more closely associated with silage NDF concentration than D-value. Intake of NDF increased with increasing concentrations of silage iNDF and pdNDF, but was more closely associated with pdNDF than with iNDF. When NDF intake was predicted using two independent variables, i.e. NDF concentration and three different parameters describing the NDF quality, prediction error of NDF intake was clearly decreased compared with other models. When NDF and iNDF concentrations were used as independent variables, the coefficient for iNDF was strongly negative indicating that at the same NDF concentration, NDF intake will decrease with increasing iNDF concentration (or decreased potential NDF digestibility).

\section{Silage fermentation characteristics}

The concentration of TA had the strongest effect of the fermentation parameters on SDMI (Table 4). However, when silage DM concentration and D-value were included in the model, the slope for TA decreased suggesting that the effects of increased in-silo fermentation on intake were

Table 2 Relationships between silage parameters and silage DM intake in studies investigating the effects of maturity of ensiled grass $(\mathrm{n}=81)^{\dagger}$

\begin{tabular}{|c|c|c|c|c|c|c|c|c|c|c|c|c|}
\hline$X_{1}$ & $X_{2}$ & Intercept & s.e. & $P$-value & Slope $_{1}$ & s.e. & $P$-value & Slope $_{2}$ & s.e. & $P$-value & RMSE & $R^{2}$ \\
\hline D-value & & -1.2 & 1.41 & 0.42 & 0.0175 & 0.0023 & $<0.001$ & & & & 0.208 & 0.940 \\
\hline D-value & $C P$ & -0.9 & 2.03 & 0.67 & 0.0168 & 0.0042 & $<0.001$ & 0.001 & 0.0059 & 0.86 & 0.209 & 0.937 \\
\hline D-value & NDF & 4.4 & 2.46 & 0.09 & 0.0124 & 0.0029 & $<0.001$ & -0.004 & 0.0014 & 0.02 & 0.192 & 0.936 \\
\hline D-value & $\mathrm{DM}$ & -3.7 & 1.46 & 0.02 & 0.0180 & 0.0022 & $<0.001$ & -0.009 & 0.0023 & 0.003 & 0.174 & 0.962 \\
\hline D-value & $\mathrm{NH}_{3}-\mathrm{N}$ & 0.3 & 1.35 & 0.80 & 0.0164 & 0.0022 & $<0.001$ & -0.010 & 0.0027 & 0.002 & 0.191 & 0.959 \\
\hline NDF & & 16.0 & 0.78 & $<0.001$ & -0.0101 & 0.0011 & $<0.001$ & & & & 0.452 & 0.640 \\
\hline OMD & & 0.0 & 1.25 & 0.98 & 0.0145 & 0.0019 & $<0.001$ & & & & 0.316 & 0.842 \\
\hline OMD & Ash & 0.1 & 1.29 & 0.93 & 0.0173 & 0.0021 & $<0.001$ & -0.027 & 0.0067 & 0.002 & 0.210 & 0.950 \\
\hline iNDF & & 12.3 & 0.50 & $<0.001$ & -0.0225 & 0.0029 & $<0.001$ & & & & 0.310 & 0.841 \\
\hline iNDF & pdNDF & 14.5 & 0.82 & $<0.001$ & -0.0186 & 0.0031 & $<0.001$ & -0.005 & 0.0016 & 0.007 & 0.255 & 0.879 \\
\hline
\end{tabular}

${ }^{\dagger} \mathrm{D}$-value $=$ digestible organic matter $(\mathrm{g} / \mathrm{kg} \mathrm{DM}), \mathrm{CP}=$ crude protein $(\mathrm{g} / \mathrm{kg} \mathrm{DM}), \mathrm{DM}=$ dry matter $(\mathrm{g} / \mathrm{kg}), \mathrm{NH}_{3}-\mathrm{N}(\mathrm{g} / \mathrm{kg}$ total $\mathrm{N}), \mathrm{NDF}=$ neutral detergent fibre $(\mathrm{g} / \mathrm{kg} \mathrm{DM}), \mathrm{iNDF}=$ indigestible NDF ( $/ \mathrm{kg} \mathrm{DM}), \mathrm{pdNDF}=$ potentially digestible NDF ( $g / \mathrm{kg} D M)$. 
Huhtanen, Rinne and Nousiainen

Table 3 Relationships between silage fibre fractions and D-value $(\mathrm{g} / \mathrm{kg} D M)$ on total NDF intake $(\mathrm{g} / \mathrm{d})(\mathrm{n}=81)^{\dagger}$

\begin{tabular}{|c|c|c|c|c|c|c|c|c|c|c|c|c|}
\hline$X_{1}$ & $X_{2}$ & Intercept & s.e. & $P$-value & Slope $_{1}$ & s.e. & $P$-value & Slope $_{2}$ & s.e. & $P$-value & RMSE & $R^{2}$ \\
\hline D-value & & 10077 & 875 & $<0.001$ & -4.22 & 1.206 & $<0.001$ & & & & 316 & 0.276 \\
\hline D-value & D-value ${ }^{2}$ & -15587 & 8937 & 0.09 & 72.6 & 26.68 & 0.01 & -0.057 & 0.0199 & 0.01 & 292 & 0.395 \\
\hline NDF & & 5001 & 443 & $<0.001$ & 4.10 & 0.768 & $<0.001$ & & & & 219 & 0.556 \\
\hline pdNDF & & 3800 & 659 & $<0.001$ & 7.37 & 1.384 & $<0.001$ & & & & 200 & 0.711 \\
\hline iNDF & & 6768 & 268 & $<0.001$ & 5.92 & 1.591 & 0.001 & & & & 310 & 0.263 \\
\hline NDF & D-value & -1587 & 1747 & 0.37 & 8.12 & 1.352 & $<0.001$ & 6.57 & 1.631 & 0.002 & 146 & 0.879 \\
\hline NDF & pdNDFD & -310 & 1645 & 0.85 & 6.72 & 1.211 & $<0.001$ & 4553 & 1304 & 0.005 & 150 & 0.837 \\
\hline NDF & iNDF & 3597 & 670 & $<0.001$ & 7.91 & 1.421 & $<0.001$ & -8.25 & 2.306 & 0.004 & 153 & 0.826 \\
\hline
\end{tabular}

${ }^{\dagger}$ D-value = digestible organic matter (g/kg DM), pdNDF = potentially digestible NDF (g/kg DM), iNDF = indigestible NDF $(g / k g$ DM), pdNDFD = potential NDF digestibility $=$ pdNDF/NDF

derived from associated changes in silage DM concentration and D-value. None of the other fermentation parameters had a significant effect on SDMl; only propionic acid had a negative trend $(P=0.15)$. The effect of silage $\mathrm{pH}$ on SDMI was negative $(P<0.01)$, but the magnitude of the response was negligble within the practical $\mathrm{pH}$ range $(-0.36 \mathrm{~kg} \mathrm{DM}$ per one $\mathrm{pH}$ unit).

\section{Silage DM concentration}

Silage DM intake increased quadratically with increasing silage DM concentration (Table 5). The maximum intake was predicted at a DM concentration of $419 \mathrm{~g} / \mathrm{kg}$. Because the effects of DM concentration on SDMI in response to wilting are partly confounded by changes in fermentation characteristics, parameters describing the fermentation quality were included in the model. This reduced the DM concentration at predicted maximum intake to 370,337 and $350 \mathrm{~g} / \mathrm{kg}$ when ammonia- $\mathrm{N}$, In(ammonia- $\mathrm{N})$ or $\mathrm{TA}$, respectively, was included in the model.

\section{Silage harvest and inclusion of legume and whole-crop} silages

In most cases the effects of silage harvest (primary growth $v$. regrowth) are confounded by differences in DM concentration, D-value and fermentation characteristics. In the present data, D-value was markedly higher for the primary growth compared with the regrowth silages (686 v. $645 \mathrm{~g} / \mathrm{kg} \mathrm{DM}$ ) but the mean differences in DM (287 v. $272 \mathrm{~g} / \mathrm{kg}$ ), ammonia N (50 v. $55 \mathrm{~g} / \mathrm{kg} \mathrm{N}$ ) and TA concentrations (59 v. $55 \mathrm{~g} / \mathrm{kg} \mathrm{DM}$ ), respectively, were relatively small.

When the intakes were corrected for the effects of D-value $(0.017 \mathrm{~kg}$ per $\mathrm{g} / \mathrm{kg} \mathrm{DM})$, TA concentration $(0.0128 \mathrm{~kg}$ per $\mathrm{g} / \mathrm{kg} \mathrm{DM})$ and DM concentration [DM effect $(\mathrm{kg} /$ day $\left.)=0.042 \mathrm{DM}-4.63 \times 10^{-5} \mathrm{DM}^{2}-5.657\right]$ to correspond the values of the standard silage (680 and $80 \mathrm{~g} / \mathrm{kg} \mathrm{DM}$ and $250 \mathrm{~g} / \mathrm{kg}$, respectively), the difference in SDMI between the primary growth and regrowth silages decreased from 1.70 to $0.44 \mathrm{~kg}$ DM per day. However, the standard error of the estimate $(0.37)$ for the harvest effect was relatively large, and it only tended $(P=0.10)$ to reach statistical significance.

Responses to replacing grass silages partially or totally with legume or whole-crop silages on SDMI could not be accurately predicted from differences in silage D-value, DM concentration or fermentation characteristics. When the cows were fed mixtures of grass and legume or wholecrop silages, the SDMI was generally higher than predicted

Table 4 Relationships between silage fermentation characteristics and silage DM intake $(\mathrm{n}=240)^{\dagger}$

\begin{tabular}{|c|c|c|c|c|c|c|c|c|c|c|c|c|c|c|}
\hline$X_{1}$ & $x_{2}$ & $x_{3}$ & $x_{4}$ & Intercept & Slope $_{1}$ & $P$-value & Slope $_{2}$ & $P$-value & $\mathrm{Slope}_{3}$ & $P$-value & Slope $_{4}$ & $P$-value & RMSE & $R^{2}$ \\
\hline TA & & & & 12.16 & -0.0154 & $<0.001$ & & & & & & & 0.299 & 0.805 \\
\hline TA & DM & & & 10.26 & -0.0144 & $<0.001$ & 0.0070 & 0.005 & & & & & 0.277 & 0.905 \\
\hline TA & DM & D-value & & 1.69 & -0.0128 & $<0.001$ & 0.0080 & 0.001 & 0.0107 & $<0.001$ & & & 0.282 & 0.911 \\
\hline LA & DM & D-value & & -2.54 & -0.0131 & $<0.001$ & 0.0103 & $<0.001$ & 0.0152 & $<0.001$ & & & 0.312 & 0.909 \\
\hline AA & DM & D-value & & -2.65 & -0.0263 & $<0.001$ & 0.0119 & $<0.001$ & 0.0153 & $<0.001$ & & & 0.377 & 0.883 \\
\hline PrA & DM & D-value & & -4.65 & -0.0751 & 0.023 & 0.0123 & $<0.001$ & 0.0172 & $<0.001$ & & & 0.436 & 0.827 \\
\hline BA & DM & D-value & & -7.00 & 0.0069 & 0.685 & 0.0132 & $<0.001$ & 0.0226 & $<0.001$ & & & 0.449 & 0.836 \\
\hline VFA & $\mathrm{DM}$ & D-value & & -3.12 & -0.0191 & 0.001 & 0.0118 & $<0.001$ & 0.0159 & $<0.001$ & & & 0.389 & 0.870 \\
\hline $\mathrm{NH}_{3}-\mathrm{N}$ & DM & D-value & & -0.28 & -0.0130 & $<0.001$ & 0.0102 & $<0.001$ & 0.0128 & $<0.001$ & & & 0.325 & 0.893 \\
\hline $\mathrm{Ln}\left(\mathrm{NH}_{3}-\mathrm{N}\right)$ & $\mathrm{DM}$ & D-value & & 4.46 & -0.946 & $<0.001$ & 0.0091 & $<0.001$ & 0.0108 & $<0.001$ & & & 0.303 & 0.900 \\
\hline LA & VFA & $\mathrm{DM}$ & D-value & 1.61 & -0.0133 & $<0.001$ & -0.0123 & 0.844 & 0.0083 & $<0.001$ & 0.0124 & $<0.001$ & 0.297 & 0.902 \\
\hline TA & $\mathrm{LA} / \mathrm{TA}$ & DM & D-value & 1.84 & -0.0130 & $<0.001$ & 0.127 & 1.000 & 0.0082 & 0.71 & 0.0119 & $<0.001$ & 0.284 & 0.909 \\
\hline TA & $\mathrm{NH}_{3}-\mathrm{N}$ & DM & D-value & 2.18 & -0.0122 & $<0.001$ & -0.0013 & 0.931 & 0.0083 & 0.40 & 0.0116 & $<0.001$ & 0.281 & 0.910 \\
\hline TA & PrA & DM & D-value & 2.56 & -0.0125 & $<0.001$ & -0.0348 & 0.770 & 0.0081 & 0.15 & 0.0112 & $<0.001$ & 0.280 & 0.906 \\
\hline
\end{tabular}

${ }^{\dagger} \mathrm{DM}=$ dry matter $(\mathrm{g} / \mathrm{kg}), \mathrm{NH}_{3}-\mathrm{N}(\mathrm{g} / \mathrm{kg}$ total $\mathrm{N}), \mathrm{TA}=$ total acids $(\mathrm{g} / \mathrm{kg} \mathrm{DM}), \mathrm{LA}=$ lactic acid $(\mathrm{g} / \mathrm{kg} \mathrm{DM}), \mathrm{AA}=$ acetic acid $(\mathrm{g} / \mathrm{kg} \mathrm{DM}), \operatorname{PrA}=\operatorname{propionic}$ acid ( $/ / \mathrm{kg} D M), B A=$ butyric acid (g/kg DM), VFA = volatile fatty acids (g/kg DM). 
Table 5 Relationships between silage dry matter (DM) concentration and silage DM intake $(\mathrm{n}=83$ for models including concentration of ammonia- $\mathrm{N}$ in total $\mathrm{N}\left(\mathrm{g} / \mathrm{kg} ; \mathrm{NH}_{3}-\mathrm{N}\right)$ and 69 for models with the concentration of total acids $(\mathrm{g} / \mathrm{kg} \mathrm{DM} ; \mathrm{TA})$ )

\begin{tabular}{|c|c|c|c|c|c|c|c|c|c|c|c|c|}
\hline$X_{1}$ & $x_{2}$ & $x_{3}$ & Intercept & $P$-value & Slope $_{1}$ & $P$-value & Slope $_{2}$ & $P$-value & $\mathrm{Slope}_{3}$ & $P$-value & RMSE & $R^{2}$ \\
\hline DM & $\mathrm{DM}^{2}$ & $\mathrm{TA}$ & 7.78 & $<0.001$ & 0.0226 & 0.01 & $-3.2 \cdot 10^{-5}$ & 0.112 & -0.0114 & 0.11 & 0.164 & 0.953 \\
\hline DM & TA & & 10.11 & $<0.001$ & 0.0041 & 0.07 & -0.0091 & 0.159 & & & 0.142 & 0.964 \\
\hline DM & $\mathrm{DM}_{2}$ & $\mathrm{Ln}\left(\mathrm{NH}_{3}-\mathrm{N}\right)$ & 8.45 & $<0.001$ & 0.0337 & $<0.001$ & $-5.0 \cdot 10^{-5}$ & 0.018 & -0.9273 & 0.02 & 0.115 & 0.972 \\
\hline DM & $\mathrm{Ln}\left(\mathrm{NH}_{3}-\mathrm{N}\right)$ & & 10.81 & $<0.001$ & 0.0066 & $<0.001$ & -0.56 & 0.055 & & & 0.114 & 0.972 \\
\hline DM & $\mathrm{DM}^{2}$ & $\mathrm{NH}_{3}-\mathrm{N}$ & 5.66 & $<0.001$ & 0.0342 & $<0.001$ & $-4.6 \cdot 10^{-5}$ & 0.015 & -0.0164 & 0.01 & 0.098 & 0.983 \\
\hline DM & $\mathrm{DM}^{2}$ & & 6.68 & $<0.001$ & 0.0198 & 0.01 & $-2.4 \cdot 10^{-5}$ & 0.114 & & & 0.131 & 0.919 \\
\hline DM & $\mathrm{NH}_{3}-\mathrm{N}$ & & 9.15 & $<0.001$ & 0.0066 & $<0.001$ & -0.010 & 0.047 & & & 0.099 & 0.980 \\
\hline DM & & & 8.68 & $<0.001$ & 0.0058 & $<0.001$ & & & & & 0.107 & 0.957 \\
\hline
\end{tabular}

from silage characteristics. The difference between the observed and predicted intake (corrected for differences in DM concentration, D-value and fermentation characteristics) for the silages containing legumes could be described by the equation:

$$
\begin{gathered}
Y=4.13( \pm 1.27) X-2.59( \pm 0.1 .22) X^{2} \\
\left(\text { RMSE }=0.789, R^{2}=0.467\right)
\end{gathered}
$$

where $X$ is the proportion of legumes in silage DM. The maximum increase for legume silages was reached at the inclusion rate of 0.80 of total silage DM and its magnitude was $1.65 \mathrm{~kg} /$ day. For the whole-crop grass silage mixtures the corresponding equation was:

$$
\begin{gathered}
Y=5.90( \pm 0.89) X-6.14( \pm 0.57) X^{2} \\
\left(\text { RMSE }=0.158, R^{2}=0.863\right)
\end{gathered}
$$

where $X$ is the proportion of whole-crop silage in total silage DM. The maximum SDMI increase of $0.42 \mathrm{~kg} /$ day was obtained when the proportion of the whole-crop silage was 0.48 of total silage DM.

\section{Silage DM intake index}

The coefficients of D-value, TA and DM concentration, silage harvest and replacement of grass with legume or wholecrop silages were integrated manually into a relative SDMI index as follows:

$$
\begin{aligned}
\text { SDMI index } & =100+10 \times[(\text { D-value }-680) \\
& \times 0.0170-(\mathrm{TA}-80) \times 0.0128 \\
& +(0.0198 \times(\mathrm{DM}-250) \\
& \left.-0.00002364 \times\left(\mathrm{DM}^{2}-250^{2}\right)\right) \\
& -0.44 \times a+4.13 \times b-2.58 \times b^{2} \\
& \left.+5.90 \times c-6.14 \times c^{2}\right]
\end{aligned}
$$

where $\mathrm{D}$-value is digestible $\mathrm{OM}(\mathrm{g} / \mathrm{kg} \mathrm{DM}), \mathrm{TA}=$ total acids $(\mathrm{g} / \mathrm{kg} \mathrm{DM}), \mathrm{DM}=$ dry matter $(\mathrm{g} / \mathrm{kg} \mathrm{DM}), a=$ proportion of regrowth grass silage of silage DM $(0-1)$, $b=$ proportion of legumes in silage $\operatorname{DM}(0-1)$ and $c=$ proportion of whole-crop silage of total silage DM $(0-1)$. When the residuals of the regression of SDMI index on SDMI were regressed against silage parameters, none of the parameters were significantly related to residuals $\left(P>0.10 ; R^{2}<0.005\right)$, i.e. the residuals were randomly distributed (data not shown).

When the possible effects of the silage variables not included in the index calculation were evaluated using them as a second independent variable in addition to SDMI index, the effect of NDF concentration became significant $(P<0.01)$ and all criteria of the goodness of fit of the equation were improved. Although quantitatively the effect was not very large, the following term describing the effect of NDF concentration was included in the index: $-0.0023 \times(\mathrm{NDF}-550)$.

The relationships between the SDMI index and silage DM intake estimated by the mixed model are shown in Table 6 . The slope of regression (0.0866) was significantly $(P<0.01)$ different from the default value of $0.10 \mathrm{~kg}$ DM per one index unit suggesting that there were some interactions between the components of the index. The deviation was greater when the effects of forage type were excluded from the model indicating that the slope bias may be associated to legume and whole-crop silages. Indeed, when the index based only on grass silage data were used for legume and whole-crop data, the relationship between SDMI index and intake was not significant $(P=0.38)$. However, when the effects of forage types were included in the index, the prediction error decreased. The slope increased and became highly significant, but still remained clearly below the default value. When the silages containing proportionally more than 0.50 of legume or whole-crop silages were excluded from the data, the prediction error clearly decreased and was not different from grass silage data.

When individual components of the index were eliminated and SDMI was predicted using the 'reduced' index, the prediction error increased most when D-value or fermentation quality was eliminated followed by the DM concentration and the harvest effect. Eliminating NDF or proportions of legume and whole-crop silages only slightly increased the prediction error (Figure 1). 
Huhtanen, Rinne and Nousiainen

Table 6 Relationships between the relative silage dry-matter (DM) intake index (SDMI-ind) and SDMI

\begin{tabular}{|c|c|c|c|c|c|c|c|c|c|c|}
\hline$X_{1}$ & $n$ & Data & Intercept & s.e. & $P$-value & Slope & s.e. & $P$-value & RMSE & $R^{2}$ \\
\hline SDMI-ind & 486 & All & 2.53 & 0.547 & $<0.001$ & 0.0866 & 0.0058 & $<0.001$ & 0.424 & 0.852 \\
\hline SDMI-ind $^{\dagger}$ & 486 & All & 3.01 & 0.637 & $<0.001$ & 0.0827 & 0.0066 & $<0.001$ & 0.468 & 0.777 \\
\hline SDMI-ind & 423 & Grass & 1.38 & 0.513 & 0.008 & 0.0988 & 0.0056 & $<0.001$ & 0.359 & 0.894 \\
\hline SDMI-ind & 456 & Grass + legume and whole crop $<0.50$ & 1.89 & 0.488 & $<0.001$ & 0.0931 & 0.0052 & $<0.001$ & 0.361 & 0.896 \\
\hline SDMI-ind & 70 & Legume and whole crop & 5.53 & 1.379 & $<0.001$ & 0.0664 & 0.0133 & $<0.001$ & 0.667 & 0.616 \\
\hline SDMI-ind $^{\dagger}$ & 70 & Legume and whole crop & 10.46 & 2.206 & $<0.001$ & 0.0210 & 0.0233 & 0.38 & 0.760 & 0.062 \\
\hline
\end{tabular}

${ }^{\dagger}$ The effects of inclusion of legume and whole-crop silages excluded from the index.

The cross-validation errors were only marginally higher than RMSE for all three data sets tested indicating a good robustness of the model (Table 7). The good performance of the model is consistent with the small range in regression coefficients between the two major components of the index, D-value and TA concentration v. SDMI. Within the six subsets, the slope of D-value ranged from 0.0150 to $0.0187 \mathrm{~kg}$ per $1 \mathrm{~g} / \mathrm{kg}$ DM and that of TA from -0.0113 to -0.0137 per $1 \mathrm{~g} / \mathrm{kg} \mathrm{DM}$, respectively. The effects of legume and whole-crop silages were not included in calibration and cross-validation models.

The animal and diet related effects on the magnitude of intake responses to one SDMI index unit are presented in Table 8. The SDMI response to one index unit increased with milk yield, DIM and LW and decreased with increasing proportion of concentrate in the diet.

\section{Discussion}

Silage digestibility as influenced by stage of maturity

The present evaluation confirmed that SDMI is strongly influenced by silage $D$-value in accordance with earlier reports (Offer et al., 1998; Huhtanen et al., 2002). Silage D-value predicted SDMI much more precisely than NDF concentration. Unfortunately NDF concentration was not analysed in earlier studies investigating the maturity effects of ensiled grass, but the decrease in prediction error was similar when based on data with analysed NDF concentration (RMSE $=0.159$ v. 0.308 ) or on the whole data with

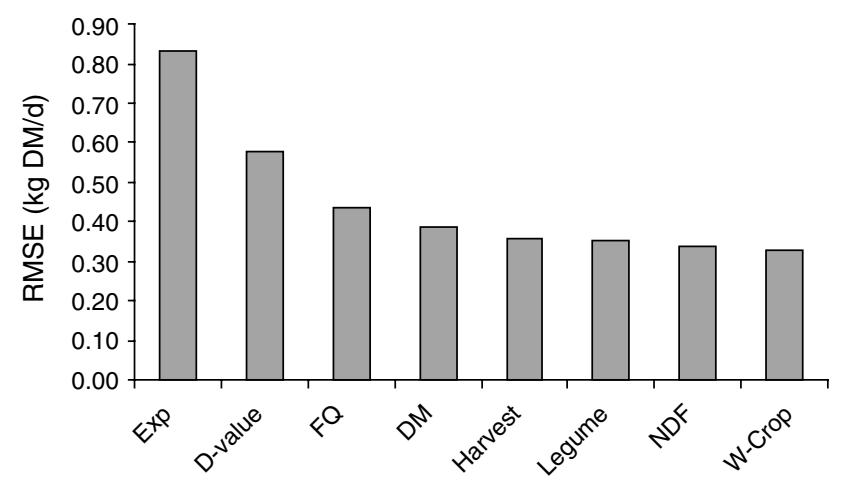

Figure 1 The effect of including new components to the silage dry-matter (DM) intake index on residual mean-square error (RMSE) of silage DM intake (Exp = RMSE after excluding random study effect; $F Q=$ fermentation quality; W-Crop = whole crop). estimated NDF concentration for 35 silages (RMSE $=0.207$ v. 0.452). In both cases, silage iNDF concentration was more closely related to SDMI than total NDF concentration demonstrating the importance of NDF quality on SDMI. The regression coefficients of the bivariate model with iNDF and pdNDF as independent variables $(-0.0186 v$ v -0.005$)$ may reflect relative differences in the turnover rates of these fibre fractions. Turn-over rate of pdNDF is much faster than that of iNDF (Rinne et al., 2002; Huhtanen et al., 2006), because pdNDF disappears from rumen both by digestion and passage but iNDF can disappear only by passage.

Although SDMI increased with increasing silage D-value, the effect of D-value on NDF intake was curvilinear with the maximum NDF intake being observed at a D-value of $640 \mathrm{~g} / \mathrm{kg}$ DM. Declining NDF intake with high silage D-values strongly suggests that factors other than rumen fill were limiting intake. Indeed, rumen NDF pool size has decreased with improved digestibility of grass silage (Bosch et al., 1992; Rinne et al., 2002; Kuoppala et al., 2004) suggesting that cows do not use all the rumen capacity when highly digestible grass silages are fed. Greater response in SDMI to increased D-value in high producing cows also suggests that rumen fill was not the limiting factor, and the cows were able to increase the intake of highly digestible silages when their energy demand increased.

Intake of digestible OM was strongly and linearly associated with silage D-value (Figure 2a), whereas NDF intake showed a quadratic pattern with the maximum intake at D-value of $640 \mathrm{~g} / \mathrm{kg}$ DM. Intake of NDF increased with increasing silage NDF concentration, but this effect was not strong enough to maintain the intake of digestible $\mathrm{OM}$, and consequently energy intake decreased with increasing fibre concentration in silage. Figure $2 \mathrm{~b}$ clearly demonstrates that the potential to consume energy was not the only factor limiting the intake of grass silage-based diets, because the cows were not able to maintain energy intake.

The present data do not support the biphasic mechanisms of intake regulation (e.g. Mertens, 1994), since no set point either for physical or metabolic feedback mechanisms could be detected. However, the data do not preclude that rumen fill has an effect on intake regulation, but it showed that it is not the only mechanism. The present data and data from rumen evacuation studies (Bosch et al., 1992; 
Table 7 Results of the cross-validation of silage dry-matter index (SDMI-ind) using whole data (A), data excluding diets using silages with $>0.50$ legume and whole-crop (B), and data from diets based on silages made from grass only (C)

\begin{tabular}{|c|c|c|c|c|c|c|c|c|c|c|c|}
\hline$X_{1}$ & $n$ & Data & & Intercept & s.e. & $P$-value & Slope & s.e. & $P$-value & RMSE & $R^{2}$ \\
\hline SDMI-ind $^{\dagger}$ & 480 & $A$ & Calibration & 2.46 & 0.516 & $<0.001$ & 0.0870 & 0.0055 & $<0.001$ & 0.401 & 0.865 \\
\hline SDMI-ind $^{\ddagger}$ & 480 & $A$ & Calibration & 2.95 & 0.605 & $<0.001$ & 0.0830 & 0.0063 & $<0.001$ & 0.445 & 0.794 \\
\hline SDMI-ind $^{\ddagger}$ & 480 & $A$ & Validation & 3.01 & 0.616 & $<0.001$ & 0.0826 & 0.0064 & $<0.001$ & 0.448 & 0.794 \\
\hline SDMI-ind $^{\dagger}$ & 457 & B & Calibration & 1.88 & 0.452 & $<0.001$ & 0.0928 & 0.0049 & $<0.001$ & 0.329 & 0.911 \\
\hline SDMI-ind $^{\ddagger}$ & 457 & B & Calibration & 1.98 & 0.518 & $<0.001$ & 0.0927 & 0.0055 & $<0.001$ & 0.350 & 0.884 \\
\hline SDMI-ind $^{\ddagger}$ & 457 & B & Validation & 2.06 & 0.534 & $<0.001$ & 0.0920 & 0.0056 & $<0.001$ & 0.355 & 0.882 \\
\hline SDMI-ind $^{\ddagger}$ & 423 & $C$ & Calibration & 1.36 & 0.473 & 0.005 & 0.0985 & 0.0052 & $<0.001$ & 0.323 & 0.912 \\
\hline SDMI-ind $^{\ddagger}$ & 423 & $C$ & Validation & 1.45 & 0.486 & $<0.001$ & 0.0978 & 0.0053 & $<0.001$ & 0.332 & 0.908 \\
\hline
\end{tabular}

${ }^{\dagger}$ Legume and whole-crop components included in the index.

${ }^{\ddagger}$ Legume and whole-crop components excluded from the index.

Rinne et al., 2002; Kuoppala et al., 2004) support the integration of physical and metabolic constraints on ruminant feed intake.

Fisher et al. (1987) proposed a model integrating the physical and metabolic constraints on ruminant feed intake. They achieved this by using a double exponential term expressing intake as a function of rumen distension and nutrient flow intending to relate the strength of each stimulus in relation to the other. Huhtanen (2002) tested this model for the data of Rinne et al. (1999) and found that the model predicted the differences in intake of the 16 diets accurately, while the biphasic model or models assuming that only rumen fill or capacity to use energy limit intake were unable to predict the intakes with reasonable accuracy. The conceptual model of Weston (1996) recognises the upper physiological limits of energy disposal and maximum rumen digesta. Over a wide range of forage qualities neither the rumen digesta upper ceiling nor the capacity to use energy limit intake alone.

The close relationship between silage D-value and the intake of digestible OM from silage (and also from the total diet, since the concentrate level was similar within each study) supports indirectly the theory proposed by Ketelaars and Tolkamp (1992) and Tolkamp and Ketelaars (1992). According to their hypothesis, the feed intake is adjusted by the animal to maximise the efficiency of oxygen utilisation and they showed that intake was closely related to q-value (metabolizable energy/gross energy) of the diet. The D-value of silage is almost completely correlated to q-value, since variation in silage gross energy and methane and urinary losses are relatively small. Furthermore, methane and urine losses are likely to be negatively correlated as proportionally higher urinary and lower methane losses of digestible energy are expected for early harvested high $\mathrm{N}$ silages.

\section{Silage fermentation characteristics}

The products of silage in-silo fermentation clearly depressed SDMI (Table 4), which is in good agreement with our previous evaluation (Huhtanen et al., 2002) and other literature data (Rook et al., 1991; Steen et al., 1995, 1998). As in our previous study (Huhtanen et al., 2002), the best single SDMI predictor was $\mathrm{TA}$, the slope being nearly the same as in the current data $(-13.6 \mathrm{v} .-13.7 \mathrm{~g}$ per $\mathrm{g} / \mathrm{kg} \mathrm{DM})$. The intake depression to TA concentration decreased with increased total DM intake $(r=0.42$; $P<0.001)$ and milk yield $(r=0.43 ; \quad P<0.001)$ suggesting that when the energy demand of the cows increase, the negative effects of extensive in-silo fermentation mediated by metabolic factors or feed palatability affect SDMI less. Interestingly, the adverse effect of TA concentration was not related to the amount of concentrate in the diet and with increasing proportion of concentrate, higher silage TA concentration depressed SDMI more $(r=0.33)$.

In contrast with our previous evaluation (Huhtanen et al., 2002), combining other silage fermentation parameters in addition to TA did not markedly improve the fit of the models and the regression coefficients of all silage fermentation parameters except TA remained non-significant (Table 4). This may partly be due to different data used in the present evaluation. Because only the studies including silage digestibility estimates were used, the data from several studies with poorly fermented silages were excluded from this study. As indicated by the $95 \%$ quantile values for silage butyric acid $(5.6 \mathrm{~g} / \mathrm{kg} D M)$, total VFA ( $47 \mathrm{~g} / \mathrm{kg}$ DM) and ammonia-N (122 g/kg total N), our dataset had only a small proportion of badly fermented silages, possibly precluding any other fermentation parameters than TA reaching statistical significance. Another explanation could be that silage D-value and DM concentration were excluded as confounding factors in the models used; i.e.

Table 8 The animal and diet related effects on the magnitude of intake responses of one silage dry-matter intake index unit

\begin{tabular}{lrrrrc}
\hline \hline Parameter $^{\dagger}$ & Intercept & \multicolumn{1}{l}{ Slope } & P-value & RMSE & $R^{2}$ \\
\hline Milk (kg/day) & 0.0649 & 0.00122 & 0.014 & 0.0261 & 0.041 \\
ECM (kg/day) & 0.0590 & 0.00142 & 0.002 & 0.0258 & 0.066 \\
DIM (days) & 0.0628 & 0.00032 & 0.001 & 0.0255 & 0.085 \\
LW (kg) & -0.0451 & 0.00025 & $<0.001$ & 0.0246 & 0.153 \\
Cprop & 0.1149 & -0.11825 & $<0.001$ & 0.0255 & 0.089 \\
\hline
\end{tabular}

${ }^{\dagger} \mathrm{ECM}=$ energy corrected milk; DIM = days in milk; $\mathrm{LW}=$ live weight; Cprop $=$ proportion of concentrate in the diet. 
Huhtanen, Rinne and Nousiainen

a)

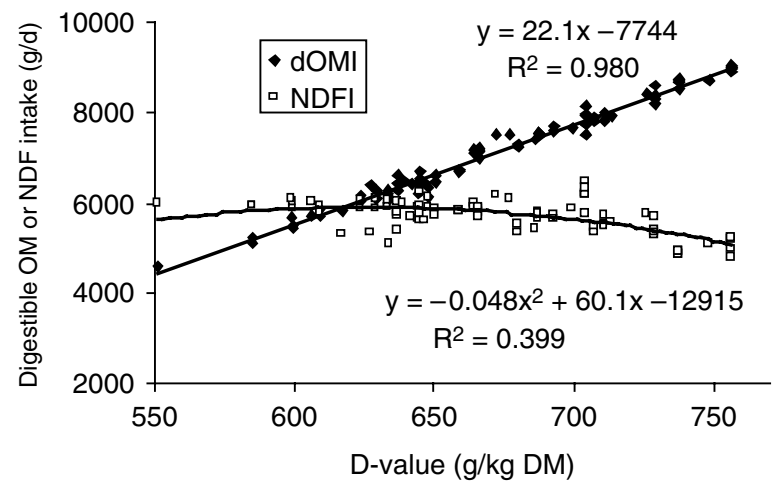

b)

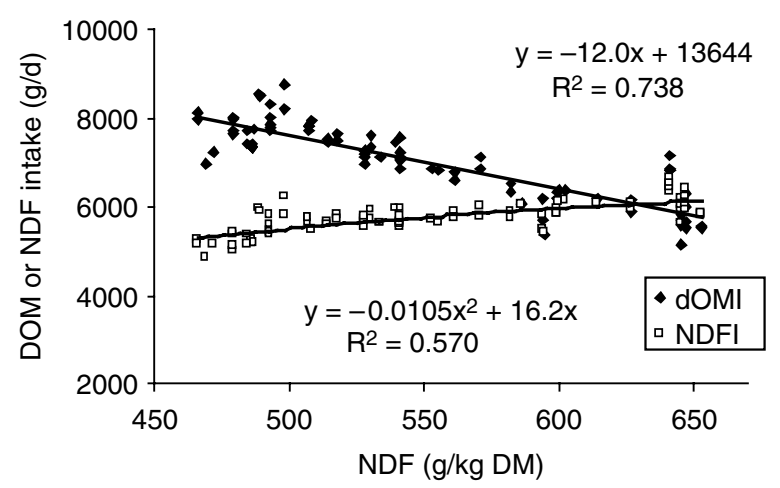

Figure 2 The effects of silage D-value and neutral-detergent fibre (NDF) concentration on silage digestible organic matter (DOM) and NDF intake. The values are adjusted for random study effects.

extensively fermented silages may have lower DM concentration and D-value contributing to their reduced intake in addition to fermentation products. For example, the effects of propionic acid (PrA) and ammonia $\mathrm{N}$ had a significant negative effect on $D$-value within a study. Including silage $D$-value and DM concentration in addition to TA in the model improved the fit markedly $\left(R^{2}=0.805\right.$ v. 0.918) and decreased the coefficient for TA slightly $(-11.1 \mathrm{~g}$ per $\mathrm{g} / \mathrm{kg} \mathrm{DM}$ ), which strongly suggests that some interactions existed between the extent of in-silo fermentation and silage DM concentration or D-value in the data.

Similarly as in the previous evaluation (Huhtanen et al., 2002), the highest absolute SDMI depression was observed for PrA, the slope being $-63 \mathrm{~g}$ per $\mathrm{g} / \mathrm{kg}$ DM (Table 4). This is in agreement with the results of Krizsan and Randby (2007), who reported an $89.6 \mathrm{~g} /$ day depression in SDMI in growing steers per one $\mathrm{g} / \mathrm{kg}$ DM increase in silage PrA. In their data PrA was the best single SDMI predictor. Although the mechanism how PrA affects SDMI remains unsolved, it seems to be universal across silage and animal types. However, the mechanism must be associated to adverse effect caused by secondary fermentation of silage rather than being a straight-forward effect of PrA. Because of the very strong specific effects of secondary fermentation products and the lack of poorly fermented silages in our dataset, the model presented herein may overestimate the intake of very poorly fermented silages.

\section{Silage DM concentration}

The present evaluation strongly implies that SDMI is independently affected by silage DM concentration (Table 5), because the slope for DM remained statistically significant in the multivariate models including the silage fermentation parameters (TA and ammonia N). The effect of DM on SDMI was curvilinear in the models including silage ammonia-N or TA in addition to the linear and quadratic DM concentration terms. Above DM concentration of $500 \mathrm{~g} / \mathrm{kg}$ the model predicts rapidly declining DM intake, but due to lack of high DM observations in the present data the estimates are obviously biased. Thus the use of the quadratic equation should be restricted to a DM range from 175 to $500 \mathrm{~g} / \mathrm{kg}$.

Many earlier data evaluations have reported positive association between forage DM concentration and DM intake (e.g. Huhtanen, 1994; Offer et al., 1998; Steen et al., 1998; Wright et al., 2000). These studies have used comparisons between direct-cut $v$. slightly or heavily wilted silages and direct-cut silage $v$. field- or barn-dried hay harvested at the same stage of grass maturity. Generally the DM intake of wilted silages have exceeded that of directcut silages the magnitude of wilting response being affected by the fermentation quality of direct-cut silage, type of additive used and weather conditions during the wilting period. Most likely a significant part of the wilting response in these studies on SDMI is related to changes in the extent and type of fermentation owing to lower water activity in wilted silages, especially when direct-cut silages are preserved without additives (Yan et al., 1996; Wright et al., 2000). To avoid this problem, we used a statistical model to account for separate effects of silage fermentation quality and DM concentration in the present evaluation.

Increased SDMI in response to wilting may be related to a shorter chop length of the silages as demonstrated by Castle (1982). The proposed mechanisms involve faster intake and/or higher turn-over rate of ruminal particle pool (Teller et al., 1990 and 1993; Kokkonen et al., 2000). For example, Teller et al. (1993) observed that the higher DM intake of wilted compared with direct-cut silage was associated with faster DM intake (40 v. $56 \mathrm{~min} / \mathrm{kg} \mathrm{DM}$ ) and shorter chop length $(3 \mathrm{v} .6 \mathrm{~cm})$ of the wilted silage. The time spent ruminating and total chewing time was not affected by the silage type, but the mean faecal particle size was significantly greater for the wilted silage suggesting a faster particle turn-over in the rumen. However, firm conclusions cannot be made, because silage DM concentration and chop length were confounded.

Huhtanen and Jaakkola (1993) did not observe any differences in ruminal NDF turnover time or passage kinetics between direct-cut silage and barn-dried hay 
harvested from the same sward. Toivonen and Heikkilä (2005) reported no response in SDMI to chopping prior to feeding of direct-cut grass silage preserved with formic acid, which suggests that reported intake responses to reduced silage particle size may be related to improved insilo fermentation rather than to particle size per se. Gordon (1981) compared precision chopped silages (same nominal chop length) without wilting (DM $192 \mathrm{~g} / \mathrm{kg}$ ) to medium or long wilting time (DM 250 or $460 \mathrm{~g} / \mathrm{kg}$ ). The SDMI in dairy cows was increased linearly in response to higher silage DM concentration (3.4 g/day per $\mathrm{g} / \mathrm{kg})$, although wilting decreased silage digestibility and increased ammonia-N concentration compared with unwilted material. Despite convincing experimental evidence of increased SDMI with higher DM, the mechanisms behind it remain unclear. However, it may be concluded that DM concentration affects intake independently in addition to changes in fermentation quality and digestibility.

Responses to inclusion of regrowth, legume and wholecrop silages

Practical experience has suggested inferior intake and production potential of regrowth silages compared to those made from primary growth of grass. This effect may at least partly have been due to analytical problems as e.g. in vitro pepsin cellulase method overestimates the regrowth silage D-value, unless separate correction equations are used for primary growth and regrowth grass material (Huhtanen et al., 2006). However, also experimental data has proven that SDMI of regrowth silages has been lower than that of primary growth silages (Peoples and Gordon, 1989; Khalili et al., 2005; Kuoppala et al., 2005a). Since regrowth silage D-value was also lower in these studies, this was to be expected.

In the present evaluation, the effect of harvest was estimated by correcting for the differences in silage D-value and fermentation characteristics, and in vitro pepsin cellulase D-values were corrected for the harvest effect. Yet a small though variable effect of the harvets could be detected. Typically regrowth grass is leafier and contains less NDF but the iNDF concentration is higher (Huhtanen et al., 2006). Kuoppala et al. (2004) reported a lower rumen NDF pool in cows consuming regrowth silages compared with primary growth silages suggesting that rumen fill was not the primary constraint of the intake of regrowth silages. The microbiological quality of regrowth grass may differ from that of primary growth as typically weather is more humid and warm later in the summer and regrowth grass may contain more dead plant material. Definite reasons for the slightly lower intake potential of regrowth silage were however difficult to identify.

Of the seven studies comparing primary growth and regrowth silages used in this evaluation, one was conducted in UK using perennial ryegrass and six in Finland using timothy-meadow fescue mixtures. The harvest effect may vary between different types of grass, and more results from ryegrass would be needed. However, when the whole data $(n=457)$ was analysed including SDMI index and the effect of cut in the model, the effect of cut was $0.10 \mathrm{~kg} /$ day showing that the index was able to predict the cut effect acceptably.

As shown by the present evaluation, the intake potential of grass silage is highly variable, and the results of replacing it with legume or whole-crop silages may vary depending on the quality of the reference grass silage used in each particular experiment. In many cases, total forage intake has however increased as a result of inclusion of legumes into grass silage (Heikkilä et al., 1992; Dewhurst et al., 2003; Kuoppala et al., 2005b). In the studies of Dewhurst et al. (2003) and Bertilsson and Murphy (2003), the NDF concentration in some legume silages, especially in white clover, was very low (250 to $300 \mathrm{~g} / \mathrm{kg} \mathrm{DM}$ ), and most likely the roles of digestibility and NDF concentration in regulating intake of these forages is small. Further, the positive SDMI responses to increased D-value achieved by earlier harvest of grass silage seem not to be as clear for legumineous silages. Kuoppala et al. (2005b) reported that a 2-week delay in the harvest of red clover silage decreased the digestibility but increased SDMI.

Cows have often been able to maintain or even increase SDMI after inclusion of whole-crop silage into the diet, although the digestibility of whole-crop silage has been lower that that of the grass silage (Hameleers, 1998; Jaakkola et al., 2001 and 2003; Patterson and Kilpatrick, 2005; Ahvenjärvi et al., 2006). One factor contributing to this effect could be the lower NDF concentration in whole-crop silages. The rumen evacuation data of Ahvenjärvi et al. (2006) showed that cows were able to increase the ruminal NDF pool at lower inclusion rates of whole-crop barley silage, but at higher inclusion rates $(0.60)$, the ruminal NDF pool started to decline. When whole-crop silages are fed at high inclusion rates, it is possible that the supply of rumen degradable nitrogen limits microbial activity in the rumen leading to reduced intake.

In conclusion, positive associative effects on total forage intake have often been found when different forages have been fed together as the intake of the a mixture of forages has been higher than that of either forage alone (Jaakkola et al., 2001; Dewhurst et al., 2003; Patterson and Kilpatrick., 2005). According to our evaluation, the quantitative responses were greater for legume than for wholecrop silage inclusion. Further, the effects of varying legume (Kuoppala et al., 2005b) or whole-crop (Jackson et al., 2004) silage quality seem not to affect SDMI and milk production as consistently as for grass silages.

\section{Silage DM intake index}

It is generally accepted that feed intake is the most important factor determining animal performance, and that the prediction of intake is a weak point in current ration formulation practices. The lack of progress is partly limited by poor understanding of the interactions between dietary, animal and management factors regulating intake. However, on a practical farm at certain time point the animal 
and management factors are relatively constant, and most of the variation in intake is related to dietary factors. Residual standard deviation in grass silage intake was $1.93 \mathrm{~kg}$ DM per day for our grass silage data set $(400$ treatment means) but only $0.84 \mathrm{~kg}$ DM per day when the variation related to the study effect resulting from differences in animals, management, supplementary feeding and also experimental procedures was excluded.

For example, when the total DM intake was predicted using the parameters of the Vadiveloo and Holmes (1979) model for the treatment means data, the parameters explained less of the total variation than the study effect (residual s.d. 0.87). The effect of D-value was not significant when included as an additional parameter to this model and its regression coefficient was only 0.001 instead of the effect of 0.017 estimated with a mixed model analysis from the studies investigating the effects of stage of grass maturity at harvest. As demonstrated elegantly by StPierre (2001), ignoring the study effect from the data-analysis can lead to erroneous statements.

For grass silages the slope of 0.099 between the relative SDMI index and observed intake response was similar to the default value of $0.100 \mathrm{~kg}$ DM per one index unit. This suggests that interactions between the different components of the index were small. However, for all silage data $(n=480)$ including legume and whole-crop silages, the prediction error increased and the slope remained below 0.100 suggesting that the same mechanisms are not regulating the intake of these silages. Due to the difficulties in predicting SDMI when either legume or whole-crop silage are fed as a sole forage (Table 6), applying the present relative SDMI index to these forages may result in high prediction errors.

Including additional components to the index decreased the prediction error (Figure 1), although the improvements achieved by the last three components (proportion of legume and whole-crop silages, silage NDF concentration) were relatively small. However, when evaluated on the basis of corrected Akaike's information criteria, inclusion of each component improved the relative likelihood for the model to be more correct. In specific cases where regrowth grass, legume or whole-crop silages are included in the diet, improvements in prediction accuracy can be substantial. Compared with our previous model (Huhtanen et al., 2002), including additional parameters (DM and NDF concentrations, and harvest) decreased the prediction error for grass silage data from 0.45 to $0.33 \mathrm{~kg} \mathrm{DM}$ per day. Adding these parameters in the model does not increase the cost of feed analysis, since DM and NDF concentrations are routinely analysed from silage samples.

Our approach to predict the relative intake potential of the silage is basically similar to earlier studies of Crampton et al. (1960) and Osbourn et al. (1974) estimating relative intake of the forage compared with standard forage and thereby eliminating the animal effects on intake. Steen et al. (1998) eliminated animal and management effects by measuring intake of 136 farm silages offered as a sole feed to beef cattle and developed a NIRS-based prediction equations using a multiple regression method. Their prediction error (residual variation) was $7.6 \%$ of the mean intake, i.e. markedly higher than $3.1 \%$ with the present relative SDMI index. They used independent test data, whereas we used cross-validation to test the model. McNamee et al. (2005) developed a model predicting the intake potential of grass silage in the supplemented diets of dairy cows. They used NIRS estimates based on the work of Steen et al. (1998). The estimates were corrected according to the relative intake between beef and dairy animals. The $R^{2}$ values of their models were around 0.70 and $93 \%$ of the predictions were within $10 \%$ of observed intakes when tested with independent data. In the present study 99.5 and $90 \%$ of the observations were within 10 and $5 \%$ of the intakes when SDMI was adjusted for random study effect. In addition, the smaller errors with our present relative SDMI index are likely to be associated with using the data from dairy cow studies using a mixed model approach rather than NIRS equations based on reference data from beef cattle. Also, in our approach each index component was systematically studied, while with farms silages used for NIRS calibration several factors affecting SDMI have varied simultaneously.

The difference observed in cross-validation of the SDMI index between RMSE $\mathrm{CV}_{\mathrm{C}}$ and RMSE values was marginal indicating that the model is robust; i.e. the smaller the difference is the better the SDMI index performs when it is applied to a new set of data. Consistent with this, coefficient of variation of the regression coefficients of major index components (D-value and TA) were only 7.8 and $4.6 \%$ between the six subsets also supporting that the relationships between intake and these silage parameters are rather universal.

Quantitative intake response per one SDMI index unit increased with forage intake, ECM yield and days in milk and decreased quadratically with the proportion of concentrate in the diet (Table 8). This is in agreement with the approach of Keady et al. (2004), who included in the total intake model both silage intake potential (FIP) and a negative interaction term of FIP $\times$ concentrate DM intake. This implies that the greatest benefits from improved intake potential of forages can be expected in high producing herds fed relatively small proportions of concentrates during established lactation.

\section{Conclusions and implications}

A relative silage DM intake index model was developed to predict changes in silage DM intake of dairy cows in response to changes in digestibility, DM and NDF concentrations, fermentation quality, harvest (primary growth $v$. regrowth) and inclusion of legume or whole-crop silages. Digestibility (D-value) explained SDMI much better than NDF, but when a parameter describing NDF quality (iNDF or potential NDF digestibility) was used, prediction error 
decreased markedly. Silage fermentation quality and DM concentration were the next most important components of the model. The model developed for grass silages was unable to predict accurately the intake responses to replacement of grass silage with legume or whole-crop silages. However, based on the SDMI index and empirical relationships, the intake of mixed silages could be predicted with reasonable accuracy when the proportion of legume and whole-crop silages was less than 0.50 of silage DM. It is important that the model is now tested against an independent data set including a wide range of variables. The weakness of our model is that it does not predict the actual intake, but responses to changes in silage characteristics. The model will improve the current ration formulation systems by facilitating to predict quantitative intake responses, and consequently responses in the nutrient supply, which are prerequisites for economic models optimising milk production in various farming systems.

\section{Acknowledgements}

We are grateful to all our colleagues, especially M.Sc. Terttu Heikkilä, who provided information of the unpublished experiments included in the data set.

\section{References}

Agnew RE, Offer NW, McNamee BF and Park RS 2001. The development of a system based on near infrared spectroscopy to predict the intake of grass silage as the sole feed by the dairy cow. In Proceedings of annual meeting of British Society of Animal Science 2001. p. 197

Ahvenjärvi S, Joki-Tokola E, Vanhatalo A, Jaakkola S and Huhtanen P 2006. Effects of replacing grass silage with barley silage in dairy cow diets. Journal of Dairy Science 89, 1678-1687.

Bertilsson J and Murphy M 2003. Effects of feeding clover silages on feed intake, milk production and digestion in dairy cows. Grass and Forage Science 58, 309-322.

Bosch MW, Lammers-Wienhoven SCW, Bangma GA, Boer $H$ and Van Adrichem PWM 1992. Influence of stage of maturity of grass silages on digestion processes in dairy cows. 2. Rumen contents, passage rates, distribution of rumen and faecal particles and mastication activity. Livestock Production Science 32, 265-281.

Castle ME 1982. Making high quality silage. In Silage for milk production (ed. JAF Rook and PC Thomas), pp. 127-150. Technical bulletin no. 2. Hannah Research Institute, UK.

Crampton EW, Donefer E and Lloyd LE 1960. A nutritive index for forages. Journal of Animal Science 19, 538-544.

Dewhurst RJ, Fisher WJ, Tweed JKS and Wilkins RJ 2003. Comparison of grass and legume silages for milk production. 1. Production responses with different levels of concentrate. Journal of Dairy Science 86, 2598-2611.

Dulphy JP, Faverdin P and Jarrige R 1989. Feed intake: the Fill Unit System. In Ruminant nutrition: recommended allowances and feed tables (ed. $R$ Jarrige), pp. 61-67, INRA, John Libbey Eurotext, Paris.

Fisher DS, Burns JC and Pond KR 1987. Modelling ad libitum dry matter intake by ruminants as regulated by distension and chemostatic feedbacks. Journal of Theoretical Biology 126, 407-418.

Gordon FJ 1981. The effect of wilting of herbage on silage composition and its feeding value for milk production. Animal Production 32, 171-178.

Hameleers A 1998. The effects of the inclusion of either maize silage, fermented whole crop wheat or urea-treated whole crop wheat in a diet based on a high-quality grass silage on the performance of dairy cows. Grass and Forage Science 53, 157-163.
Heikkilä T, Toivonen V and Mela T 1992. Comparison of red-clover grass silage with grass silage for milk production. In Proceedings of the 14th general meeting of the European Grassland Federation, June 8-11, 1992, Lahti, Finland (ed. P Pärssinen, 0 Niemeläinen, L Tervonen and S Lehtinen), pp. 388-391

Huhtanen P 1994. Factors influencing forage intake. In Forage: Seeding to feeding (ed. A Fredeen), pp. 103-127. Proceedings of the Nova Scotia Forage Conference, October 29-30, 1993.

Huhtanen P 2002. New developments in the prediction of intake of silage-based diets. In Proceedings of the XIIIth international silage conference (ed. LM Lechie and C Thomas), pp. 236-251. SAC, Auchincruive, Scotland.

Huhtanen $P$ and Jaakkola $S$ 1993. The effects of forage preservation method and proportion of concentrate o digestion of cell wall carbohydrates and rumen digesta pool size in cattle. Grass and Forage Science $48,155-165$

Huhtanen $\mathrm{P}$, Khalili $\mathrm{H}$, Nousiainen J, Rinne $\mathrm{M}$, Jaakkola S, Heikkilä T and Nousiainen J 2002. Prediction of the relative intake potential of grass silage by dairy cows. Livestock Production Science 73, 111-130.

Huhtanen P, Nousiainen J and Rinne M 2006. Recent developments in forage evaluation with special reference to practical applications. Agricultural and Food Science 15, 293-323.

Huhtanen P, Asikainen U, Arkkila M and Jaakkola S 2007. Cell wall digestion and passage kinetics estimated by marker and in situ methods or by rumen evacuations in cattle fed hay 2 or 18 times daily. Animal Feed Science and Technology 133, 206-227.

Jaakkola S, Saarisalo E and Heikkilä T 2001. Whole-crop barley silage for dairy cows. In Production and utilization of silage, with emphasis on new techniques, pp. 69-74. NJF seminar no. 326, September 27-28, 2001. Lillehammer, Norway.

Jaakkola S, Saarisalo E and Heikkilä T. 2003. Concentrate supplementation of dairy cow diet based on whole crop barley and wheat silage. In Agriculture in global perspective (ed. 0 Niemeläinen and M Topi-Hulmi), p. 10. Proceedings of the NJF's 22nd congress, July 1-4, 2003. Turku, Finland

Jackson MA, Readman RJ, Huntington JA and Sinclair LA 2004. The effect of processing at harvest and cutting height of urea-treated whole-crop wheat on performance and digestibility in cows. Animal Science 78, 467-476.

Keady TWJ, Mayne S, Offer NW and Thomas C 2004. Prediction of voluntary intake. In Feed into milk (ed. C Thomas), pp. 1-7. Nottingham University Press, Nottingham, UK.

Ketelaars JJMH and Tolkamp BJ 1992. Toward a new theory of feed intake regulation in ruminants. 1. Causes of differences in voluntary feed intake: critique of current views. Livestock Production Science 30, 269-296.

Khalili $H$, Sairanen A, Nousiainen JI and Huhtanen P 2005. Effects of silage made from primary or regrowth grass and protein supplementation on dairy cow performance. Livestock Production Science 96, 269-278.

Kokkonen T, Tuori M, Leivonen V and Syrjälä-Qvist L 2000. Effect of silage dry matter content and rapeseed meal supplementation on dairy cows. 1. Milk production and feed utilisation. Animal Feed Science and Technology 84, 213-228.

Kuoppala K, Rinne M, Ahvenjärvi S, Nousiainen J and Huhtanen P 2004. Digestion kinetics of NDF in dairy cows fed silages from primary growth and regrowth of grass. Journal of Animal and Feed Sciences 13, (suppl. 1) 127-130.

Kuoppala K, Rinne M, Nousiainen J and Huhtanen P 2005a. The effect of harvesting strategy of grass silage on milk production. In Proceedings of the $X X$ international grassland congress: offered papers (ed. FP O'Mara, RJ Wilkins, L't Mannetje, DK Lovett, PAM Rogers and TM Boland), p. 484. Wageningen Academic Publishers, The Netherlands.

Kuoppala K, Ahvenjärvi S, Rinne M and Vanhatalo A 2005b. NDF digestion in dairy cows fed grass or red clover silages cut at two stages of growth. In Silage production and utilization (ed. RS Park and MD Stronge), p.164. Proceedings of the XIVth international silage conference, July 2005, Belfast, Northern Ireland.

Krizsan SJ and Randby $\AA$ 2007. The effect of fermentation quality on the voluntary intake of grass silage by growing cattle fed silage as the sole feed. Journal of Animal Science 85, 984-996.

Littel RC, Milliken GA, Stroup WW and Wolfinger RD 1996. SAS ${ }^{\circledR}$ system for mixed models. SAS Institute Inc., Cary, NC. 
McNamee BF, Woods VB, Kilpatrick DJ, Mayne CS, Agnew RE and Gordon FJ 2005. The prediction of the intake potential of grass silage in the supplemented diets of lactating dairy cows. Livestock Production Science 92, 233-240.

Mertens DR 1994. Regulation of forage intake. In Forage quality, evaluation and utilization (ed. GC Fahey Jr), pp. 450-493, American Society of Agronomy, Madison, WI.

National Research Council 2001. Nutrient requirements of dairy cattle, seventh revised edition. National Academy Press, Washington, DC.

Offer NW, Percival DS, Dewhurst RJ and Thomas C 1998. Prediction of the voluntary intake potential of grass silage by sheep and dairy cows from laboratory silage measurements. Animal Science 66, 357-367.

Osbourn DF, Terry RA, Outen GE and Cammel SB 1974. The significance of determination of cell walls as the rational basis for the nutritive evaluation of forages. Proceedings of the XII international grassland congress, vol. 3, June 11-20, 1974. Moscow, USSR, pp. 374-380

Patterson DC and Kilpatrick DJ 2005. The effects of maize and whole crop wheat silages and quality of grass silage on the performance of lactating dairy cows. In Silage production and utilization (ed. RS Park and MD Stronge), p. 165. Proceedings of the XIVth international silage conference, July 2005, Belfast, Northern Ireland. Wageningen Academic Publishers, The Netherlands.

Peoples AC and Gordon FJ 1989. The influence of wilting and season of silage harvest and the fat and protein concentration of the supplement on milk production and food utilization by lactating cattle. Animal Production 48, 305-317.

Rinne M, Jaakkola S, Kaustell K, Heikkilä T and Huhtanen P 1999. Silage harvested at different stages of grass growth versus concentrate foods as energy and protein sources in milk production. Animal Science 69, 251-263.

Rinne $M$, Huhtanen $P$ and Jaakkola S 2002. Digestive processes of dairy cows fed silages harvested at four stages of grass maturity. Journal of Animal Science 80, 1986-1998.

Rook AJ, Gill M, Willink RD and Lister SJ 1991. Prediction of voluntary intake of grass silages by lactating cows offered concentrates at a flat rate. Animal Production 52, 407-420.

Sjaunja LO, Baevre L, Junkkarinen L, Pedersen J and Setälä J 1991. A Nordic proposal for an energy corrected milk (ECM) formula. In Proceedings of the 27th biennial session of the International Committee for Animal Recording (ed. P Gaillon and Y Chabert), pp. 156-157, Paris, France, July 2-6, 1990. EAAP Publication No. 50, Pudoc Wageningen, The Netherlands.

Steen RWJ, Gordon FJ, Mayne CS, Poots RE, Kilpatrick DJ, Unsworth EF, Barnes RJ, Porter MG and Pippard CJ 1995. Prediction of the intake of grass silage by cattle. In Recent advances in animal nutrition - 1995 (ed. PC Garnsworthy and DJA Cole), pp. 67-89. Butterworths, London.

Steen RWJ, Gordon FJ, Dawson LER, Park RS, Mayne CS, Agnew RE, Kilpatrick DJ and Porter MG 1998. Factors affecting the intake of grass silage by cattle and prediction of silage intake. Animal Science 66, 115-127.

St-Pierre NR 2001. Integrating quantitative findings from multiple studies using mixed model methodology. Journal of Dairy Science 84, 741-755.

Teller E, Vanbelle M, Katamali G, Collignon G, Page B and Matanu B 1990. Effects of chewing behaviour and ruminal digestion processes on voluntary intake of grass silages by lactating dairy cows. Journal of Animal Science 68, 3897-3904.

Teller E, Vanbelle $M$ and Katamali $P$ 1993. Chewing behaviour and voluntary grass silage intake by cattle. Livestock Production Science 33, 215-227.

Toivonen V and Heikkilä T 2005. The effect of chop length and additive on silage intake and milk production in cows. In Silage production and utilisation (ed. RS Park and MD Stronge), p. 140. Proceedings of the XIVth international silage conference, July 2005, Belfast, Northern Ireland.

Tolkamp BJ and Ketelaars JJMH 1992. Toward a new theory of feed intake regulation in ruminants. 2. Costs and benefits of feed consumption: an optimization approach. Livestock Production Science 30, 297-317.

Vadiveloo J and Holmes W 1979. Prediction of the voluntary feed intake of dairy cows. Journal of Agricultural Science, Cambridge 93, 553-562.

Weston RH 1996. Some aspects of constraints of forage consumption by ruminants. Australian Journal of Agricultural Research 47, 175-197.

Wright DA, Gordon FJ, Steen RWJ and Patterson DC 2000. Factors influencing the response in intake of silage and animal performance after wilting of grass before ensiling: a review. Grass and Forage Science 55, 1-13.

Yan T, Patterson DC, Gordon FJ and Porter MG 1996. The effects of wilting of grass prior to ensiling on the response to bacterial inoculation. 2. Intake and animal performance by dairy cattle over three harvest. Animal Science 62 , 419-429. 